\title{
Komparasi Hasil Belajar Matematika dengan Pembelajaran Kooperatif Metode Tutor Sebaya dan Metode SQ4R Setting Kooperatif
}

\author{
Amran Yahya ${ }^{1 *}$, Nur Wahidah Bakri ${ }^{2}$ \\ 1. Pendidikan Matematika, Fakultas Keguruan dan Ilmu Pendidikan, Universitas Sulawesi Barat \\ 2. SMK Negeri 1 Tinambung, Dinas Pendidikan dan Kebudayaan, Provinsi Sulawesi Barat \\ *email:amranyahya@unsulbar.ac.id ${ }^{1}$, idalicious08@gmail.com²
}

\begin{abstract}
Abstrak
Penelitian ini merupakan penelitian quasi-eksperimen. Tujuan yang dibahas dalam penelitian ini adalah mengetahui perbedaan hasil belajar matematika siswa kelas XAP SMK dengan pembelajaran kooperatif metode tutor sebaya dan metode SQ4R setting kooperatif. Dalam penelitian ini sampel dipilih dengan metode cluster random sampling dengan memilih siswa dari dua kelas. Data hasil belajar dikumpulkan dengan tes hasil belajar dan dianalisis dengan uji deskriptif dan inferensial menggunakan SPSS 20. Analisis deskriptif hasil belajar dengan pembelajaran kooperatif metode tutor sebaya memiliki nilai rata-rata 82,22 , berada pada kategori tinggi, rata-rata $\mathrm{N}$-Gain diperoleh nilai 0.609 kategori sedang, hasil belajar menggunakan metode SQ4R setting kooperatif memperoleh nilai rata-rata 81,38 berada pada kategori tinggi, nilai N-Gain 0.612 berada pada kategori sedang, sedangkan analisis infirensial hipotesis dengan uji t, diperoleh $t$ hitung hasil belajar Paired Sample Test adalah 0,430 dan nilai signifikansi $\mathrm{p}=0,670>0,05$. Secara umum dapat disimpulkan bahwa tidak ada perbedaan yang signifikan hasil belajar dengan pembelajaran kooperatif metode tutor sebaya dengan metode SQ4R setting kooperatif.
\end{abstract}

Kata kunci: Hasil Belajar, Metode SQ4R, Metode Tutor Sebaya.

\section{PENDAHULUAN}

Pendidikan adalah bagian penting yang menjadi dasar untuk kehidupan manusia, termasuk anak-anak dan orang dewasa. Pendidikan merupakan hak dasar yang harus dimiliki setiap anak, terlepas dari latar belakang pendidikan atau ras mereka. Dunia pendidikan dituntut memberikan konstribusi nyata dalam upaya meningkatkan kemajuan bangsa. Selain itu pendidikan juga dituntut untuk membentuk manusia yang berakhlak mulia, kreatif, mandiri dan bertanggung jawab, yang semuanya itu berdasarkan atas ketakwaan terhadap Tuhan Yang Maha Esa.

Dalam UU No.20 Tahun 2003 Tentang Sistem Pendidikan Nasional Pasal 3, menjabarkan tujuan Pendidikan nasional adalah mengembangkan potensi peserta didik agar menjadi manusia yang beriman dan bertakwa kepada Tuhan Yang Maha Esa, berakhlak mulia, sehat, berilmu, cakap, kreatif, mandiri, dan menjadi warga negara yang demokratis serta bertanggung jawab. Secara formil pendidikan berorientasi pada sekolah. Komponen utamanya ialah adanya pendidik (guru) dan peserta didik (siswa). Guru dan siswa adalah unsur manusiawi dalam pendidikan. Guru Indonesia memiliki keahlian yang tinggi sebagai sumber daya utama untuk mewujudkan tujuan 
pendidikan nasional yaitu berkembangnya potensi siswa agar menjadi manusia yang beriman dan bertakwa kepada Tuhan Yang Maha Esa (Mudlofir, 2013).

Pelaksanaan Pendidikan di sekolah bertumpu pada proses belajar mengajar. Belajar adalah suatu proses kompleks yang terjadi pada semua orang yang berlangsung seumur hidup (Siagian, 2015). Karena kompleksnya masalah belajar banyak sekali teori yang menjelaskan bagaimana proses belajar itu terjadi. Menurut Hamalik (2009) "belajar adalah modifikasi atau memperteguh kelakuan melalui pengalaman (learning is defined as the modification or strengthening of behavior through experiencing)". Abdurrahman dan Mulyono (2009) menyatakan "belajar adalah suatu bentuk pertumbuhan atau perubahan dalam diri seseorang yang dinyatakan dalam cara-cara bertingkah laku yang baru berkat pengalaman dan latihan". Dengan kata lain belajar adalah proses perubahan perilaku berkat pengalaman dan latihan yang berorientasi pada perubahan tingkah laku, baik menyangkut tentang pengetahuan, keterampilan, maupun sikap, sehingga hakekat dari belajar itu sendiri adalah perubahan. Perubahan dalam artian bahwa pengetahuan, keterampilan dan sikap melalui berbagai pengalaman seperti terlibat langsung dalam masalah yang dihadapi ataupun melakukan latihan latihan secara terus menerus sehingga terjadilah perubahan tingkah laku yang tadinya tidak tahu menjadi tahu, yang tadinya belum menguasai keterampilan tertentu akhirnya dikuasai yang tadinya sikap yang salah menjadi benar, sehingga apa yang diinginkan dalam proses tersebut dapat tercapai.

Perkembangan zaman yang pesat memberi tantangan bagi para pendidik dalam meningkatkan kompetensi dan pengetahuan bagi siswa dengan keterampilan atau kecakapan hidup. Melalui keterampilan yang tidak semata-mata mengandalkan kemampuan akademik melainkan juga non akademik, maka siswa dapat memaknai perjalanan hidupnya dengan kearifan. Untuk mewujudkan keterampilan tersebut diatas dibutuhkan adanya perpaduan antara media dan metode yang digunakan. Melalui usaha meningkatkan mutu pendidikan di sekolah, berbagai upaya telah dilakukan oleh berbagai pihak dalam bidang Pendidikan. Diantaranya dengan penyusunan kurikulum Pendidikan yang telah disempurnakan, peningkatan kompetensi guru / tenaga pendidik, pemamfaatan media pembelajaran, penataan organisasi dan manajemen pendidikan.

Kenyataan menunjukkan bahwa dalam proses pembelajaran masih banyak para guru pelajaran yang menggunakan satu jenis model pengajaran yang di anggap konvensional, sehingga pola pengajaran tidak mengalami perubahan dan perkembangan. Jika dalam pengajaran tidak menggunakan metode, strategi, teknik, dan model pembelajaran yang tepat, maka siswa akan kesulitan dalam memahami materi yang diajarkan. Matematika merupakan salah satu bidang studi yang menduduki peranan penting dalam pendidikan. Hal ini dapat dilihat dari waktu jam sekolah lebih banyak dibanding pelajaran lain. Pelajaran matematika dalam pelaksanaan pendidikan mulai dari sekolah dasar sampai perguruan tinggi.

Dalam proses pembelajaran matematika guru hendaknya memilih berbagai variasi pendekatan, strategi, metode yang sesuai dengan situasi sehingga tujuan pembelajaran yang direncanakan akan tercapai. Perlu diketahui bahwa baik atau tidaknya suatu pemilihan model atau strategi pembelajaran akan tergantung tujuan pembelajarannya, kesesuaian dengan materi pembelajaran, tingkat perkembangan peserta didik, kemampuan guru dalam mengelola pebelajaran serta 
mengoptimalkan sumber-sumber belajar yang ada. Pada kenyataannya proses pembelajaran yang banyak digunakan sering kali membuat jenuh para siswa.

Pembelajaran matematika cenderung teacher-centered sehingga peserta didik menjadi pasif. Proses pembelajaran tersebut hanya diarahkan kepada kemampuan pesrta didik untuk menghafal informasi, otak anak dipaksa untuk mengingat dan menimbun berbagai informasi tanpa dituntut untuk memahami informasi yang diingatnya dan menghubungkannya dengan kehidupan seharihari. Pendidik bertindak sebagai penyampai informasi secara aktif, sementara peserta didik pasif mendengarkan dan menyalin. Pendidik sesekali bertanya dan siswa menjawab. Pendidik memberikan contoh soal dilanjutkan memberikan latihan soal yang sifatnya rutin dan kurang melatih daya nalar, sehingga mengakibatkan kegiatan pembelajaran yang membosankan bagi peserta didik (Trianto, 2009). Untuk mengatasi permasalahan tersebut dapat dilakukan dengan memilih berbagai variasi pendekatan, strategi, metode yang sesuai dengan situasi sehingga tujuan pembelajaran yang direncanakan akan tercapai. Perlu diketahui bahwa baik atau tidaknya suatu pemilihan model atau strategi pembelajaran akan tergantung tujuan pembelajarannya, kesesuaian dengan materi pembelajaran, tingkat perkembangan peserta didik, kemampuan guru dalam mengelola pebelajaran serta mengoptimalkan sumber-sumber belajar yang ada.

Salah satu model pembelajaran di antaranya adalah model pembelajaran kooperatif yaitu suatu model pembelajaran yang menggunakan kelompok-kelompok, dengan kekhasan dari model tersebut adalah setiap siswa dalam kelompok-kelompok yang mempunyai tingkat kemampuan, budaya, etnis, sosial yang berbeda-beda, mengutamakan kerja sama untuk menyelesaikan permasalahan serta menerapkan pengetahuan dan keterampilan untuk mencapai tujuan pembelajaran. Model pembelajaran kooperatif merupakan suatu model pembelajaran yang membantu siswa untuk mengembangkan pemahaman dan sikapnya sesuai dengan kehidupan nyata di masyarakat, sehingga dengan bekerja secara bersama-sama di antara sesama anggota kelompok akan meningkatkan motivasi, produktifitas, dan perolehan belajar (Fitari dkk, 2015).

Model pembelajaran kooperatif merupakan model pembelajaran yang banyak digunakan dan menjadi perhatian serta dianjurkan oleh para ahli pendidikan. Hal ini dikarenakan berdasarkan hasil penelitian yang dilakukan oleh Slavin (dalam Rusman, 2013), dinyatakan bahwa: (1). Penggunaan pembelajaran kooperatif dapat meningkatkan prestasi belajar siswa dan sekaligus dapat meningkatkan prestasi belajar siswa dan sekaligus dapat meningkatkan hubungan sosial, menumbuhkan sikap, toleransi, dan menghargai pendapat orang lain, (2). Pembelajaran kooperatif dapat memenuhi kebutuhan siswa dalam berpikir kritis, memecahkan masalah, dan mengintegrasikan pengetahuan dan pengalaman. Dengan alasan, pembelajaran kooperatif diharapkan mampu meningkatkan kualitas pembelajaran.

Terdapat beberapa metode yang dapat diterapkan dengan model pembelajaran kooperatif diantaranya metode tutor sebaya dan metode SQ4R. Menurut Susilowati (Indriani dan Mutmainnah, 2014) tutor sebaya adalah seorang murid membantu belajar murid lainnya dengan tingkat kelas yang sama. Metode tutor sebaya dilakukan dengan cara memberdayakan kemampuan siswa yang memiliki daya serap tinggi, siswa tersebut mengajarkan materi kepada teman-temannya yang belum paham sehingga memenuhi ketuntasan belajar semuanya. Jadi, diharapkan dengan adanya tutor sebaya, peserta didik yang kurang aktif menjadi aktif. Dalam kelas tutor sebaya, tugas 
guru adalah sebagai fasilitator, mediator, motivator dan evaluator. Melalui pembelajaran tutor Sebaya diharapkan dapat memberikan motivasi kepada siswa agar memperoleh hasil belajar yang baik khususnya dalam mata pelajaran matematika.

Metode SQ4R adalah metode membaca yang efisien dan membantu siswa untuk lebih memahami suatu bacaan, serta mengarahkan siswa menemukan intisari dari bacaan tersebut. "SQ4R" adalah singkatan dari survey, question, read, recite, record, dan review, yang juga merupakan langkah-langkah dalam melaksanakan metode SQ4R. Metode SQ4R menyediakan cara sistematis dalam membaca. Penggunaaan Metode SQ4R dapat membuat siswa lebih aktif dalam proses belajar mengajar dan dapat meningkatkan hasil belajar matematika siswa. Menggunakan Metode SQ4R juga dapat merubah proses belajar mengajar matematika yang lebih menarik dan tidak hanya dinominasi oleh guru, tetapi siswa ikut aktif didalam proses pembelajaran matematika (Azlinah dan Masriyah, 2014).

Melalui pembelajaran kooperatif metode tutor Sebaya dan metode $S Q 4 R$ setting kooperatif diharapkan dapat memberikan motivasi kepada siswa agar memperoleh hasil belajar yang baik khususnya dalam mata pelajaran matematika, serta dapat membuat siswa merubah pola pikir untuk aktif dalam proses pembelajaran dan bekerja bersama-sama untuk mencapai tujuan khusus atau menyelesaikan sebuah tugas.

\section{Metode}

Jenis Penelitian adalah penelitian quasi-eksperimen yang menyajikan tentang perbandingan hasil belajar matematika siswa yang diajar dengan menggunakan pembelajaran kooperatif metode tutor sebaya dan siswa yang diajar dengan menggunakan metode SQ4R setting kooperatif.

Desain penelitian ini dirancang untuk membandingkan dua kelas eksperimen. Salah satu dari kelas eksperimen tersebut menggunakan pembelajaran kooperatif metode tutor sebaya dan kelas satunya lagi menggunakan metode SQ4R setting kooperatif. Desain penelitian yang digunakan adalah Pretest-Posttest Control Group Design, dalam desain ini terdapat dua kelompok yang dipilih secara cluster random sampling. Adapun desain penelitian ini adalah sebagai berikut:

Tabel 1. Desain penelitian Pretest-Posttest Control Group Design

\begin{tabular}{ccc}
\hline $\mathrm{O}_{1}$ & $\mathrm{X}$ & $\mathrm{O}_{3}$ \\
$\mathrm{O}_{2}$ & & $\mathrm{O}_{4}$ \\
\hline
\end{tabular}

Sugiyono (2012)

\section{Keterangan:}

$\mathrm{O}_{1} \quad$ : Pretest pada kelas eksperimen I

$\mathrm{O}_{2} \quad$ : Posttest pada kelas eksperimen I

$\mathrm{O}_{3} \quad$ : Pretest pada kelas eksperimen II

$\mathrm{O}_{4} \quad$ : Posttest pada kelas eksperimen II

X : Perlakuan (Treatment) 
Instrumen penelitian yang digunakan untuk memperoleh data adalah berupa soal tes uraian (essay) untuk mengetahui hasil belajar matematika siswa, baik pada eksperimen I maupun eksperimen II setelah siswa melalui proses belajar mengajar matematika. Tes hasil belajar merupakan tes uraian yang digunakan untuk mengukur tingkat penguasan bahan ajar siswa, tes ini terdiri atas: Pretest adalah untuk mengukur penguasaan awal siswa terhadap materi pelajaran sebelum pelaksanaan pembelajaran, Posttest adalah untuk mengukur penguasaan bahan ajar siswa setelah pelaksanaan proses pembelajaran.

Teknik pengumpulan data dalam penelitian ini adalah kita menguji kemampuan hasil belajar matematika kepada kedua kelompok yaitu kelompok eksperimen I dan kelompok eksperimen II. secara bersamaan untuk dua kelas. Proses kamampuan hasil belajar ini dilakukan dengan pengawasan yang ketat dari dua orang pengawas agar tidak terjadi kerjasama antar siswa.

Teknik analisis data yang digunakan dalam penelitian ini yaitu analisis statistik deskriftif dan inferensial. Penelitian ini dianalisis dengan menggunakan program siap pakai yakni SPSS

1. Statistika Deskriptif

Statistik deskriptif digunakan untuk mendeskripsikan karakteristik responden berupa rata-rata keterampilan matematika dan standar deviasi, baik responden pada kelas eksperimen 1 maupun responden pada kelas eksprimen II. Keperluan analisis digunakan distribusi frekuensi presentase rata-rata dan standar deviasi untuk masing-masing kelompok.

2. Statistika Inferensial

Statistik inferensial digunakan untuk menguji hipotesis penelitian yaitu dengan uji $t$ (Distribusi student t). Sebelum dilakukan uji normalitas dan uji homogenitas varians dari data keterampilan matematika siswa.

Mengetahui tingkat penguasaan materi, baik kepada kelompok eksperimen I dengan pembelajaran kooperatif metode tutor sebaya maupun pada kelompok eksperimen II yang digunakan dalam metode SQ4R setting kooperatif.

Tabel 2. Tingkat Penenetuan Kategori Tinggi Keterampilan Matematika

\begin{tabular}{cc}
\hline Tingkat Penguasaan & Kategori \\
\hline $0 \%-39 \%$ & Sangat Rendah \\
$40 \%-54 \%$ & Rendah \\
$55 \%-74 \%$ & Sedang \\
$75 \%-89 \%$ & Tinggi \\
$90 \%-100 \%$ & Sangat Tinggi \\
\hline
\end{tabular}

\section{Hasil}

Hasil analisis statistika deskriptif pada lampiran dimaksudkan untuk mendeskripsikan karakteristik responden penelitian masing-masing perlakuan. Untuk keperluan tersebut dipergunakan tabel frekuensi, persentase, rata-rata, skor tertinggi, skor terendah dan standar deviasi masing-masing perlakuan. Penyajian karakteristik responden untuk setiap perlakuan adalah sebagai berikut: 
a. Hasil Belajar Matematika Siswa sebelum diajar dengan menggunakan pembelajaran kooperatif metode tutor sebaya.

Hasil analisis statistik deskriptif berkaitan dengan skor variabel hasil belajar matematika siswa sebelum diajar dengan menggunakan pembelajaran kooperatif metode tutor sebaya disajikan dalam tabel berikut:

Tabel 3. Statistik deskriptif hasil belajar matematika siswa (Pre-test) sebelum diajar dengan pembelajaran kooperatif metode tutor sebaya.

\begin{tabular}{cc}
\hline Statistik & Nilai Statistik \\
\hline Ukuran sampel & 32 \\
Rata-rata & 53,53 \\
Nilai Tengah & 54,50 \\
Standar Deviasi & 10,12 \\
Variansi & 102,45 \\
Rentang Skor & 45 \\
Nilai Terendah & 30 \\
Nilai Tertinggi & 75 \\
\hline
\end{tabular}

Jika skor hasil belajar matematika siswa kelas XAP SMK sebelum diterapkan pembelajaran kooperatif metode tutor sebaya dikelompokkan dalam lima kategori menurut Nurkancana (1986), maka diperoleh tabel distribusi frekuensi dan presentase hasil belajar seperti ditunjukkan pada tabel berikut ini:

Tabel 4. Distribusi Frekuensi hasil belajar matematika siswa (Pre-test) sebelum diajar dengan pembelajaran kooperatif metode tutor sebaya.

\begin{tabular}{cccc}
\hline Statistik & Kategori & Frekuensi & Persentase (\%) \\
\hline $0-54$ & Sangat rendah & 16 & 50 \\
$55-64$ & Rendah & 10 & 31 \\
$65-79$ & Sedang & 6 & 19 \\
$80-89$ & Tinggi & 0 & 0 \\
$90-100$ & Sangat tinggi & 0 & 0 \\
\hline Jumlah & & 32 & 100 \\
\hline
\end{tabular}

b. Hasil belajar matematika siswa setelah diajar dengan menggunakan pembelajaran kooperatif metode tutor sebaya (Posttest)

Hasil analisis statistik deskriptif berkaitan dengan skor variabel hasil belajar matematika siswa setelah diajar dengan menggunakan pembelajaran kooperatif metode tutor sebaya disajikan dalam tabel berikut. 
Tabel 5. Statistik Deskriptif hasil belajar matematika siswa (Post-test) setelah diajar dengan pembelajaran kooperatif metode tutor sebaya

\begin{tabular}{cc}
\hline Statistik & Nilai Statistik \\
\hline Ukuran sampel & 32 \\
Rata-rata & 82,22 \\
Nilai Tengah & 82,50 \\
Standar Deviasi & 7,29 \\
Variansi & 53,08 \\
Rentang Skor & 28 \\
Nilai Terendah & 70 \\
Nilai Tertinggi & 98 \\
\hline
\end{tabular}

Jika skor hasil belajar matematika siswa kelas XAP SMK setelah diterapkan pembelajaran kooperatif metode tutor sebaya dikelompokkan dalam lima kategori menurut Nurkancana (1986), maka diperoleh tabel distribusi frekuaensi dan presentase hasil belajar seperti ditunjukkan pada tabel berikut ini:

Tabel 6. Distribusi Frekuensi Hasil belajar matematika siswa (Post-test) setelah diajar dengan pembelajaran kooperatif metode tutor sebaya

\begin{tabular}{cccc} 
Statistik & Kategori & Frekuensi & Persentase (\%) \\
\hline $0-54$ & Sangat rendah & 0 & 0 \\
$55-64$ & Rendah & 0 & 0 \\
$65-79$ & Sedang & 11 & 34 \\
$80-89$ & Tinggi & 17 & 53 \\
$90-100$ & Sangat tinggi & 4 & 13 \\
\hline Jumlah & & 32 & 100 \\
\hline
\end{tabular}

c. Hasil belajar matematika siswa setelah diajar dengan menggunakan metode PQ4R setting kooperati (Pretest)

Hasil analisis statistik deskriptif berkaitan dengan skor variabel hasil belajar matematika siswa sebelum diajar dengan menggunakan metode PQ4R setting kooperatif disajikan dalam tabel 7 berikut:

Tabel 7. Statistik deskriptif hasil belajar matematika siswa (Pre-test) sebelum diajar dengan metode PQ4R setting kooperatif.

\begin{tabular}{cc}
\hline Statistik & Nilai Statistik \\
\hline Ukuran sampel & 32 \\
Rata-rata & 52,59 \\
Nilai Tengah & 54,00 \\
Standar Deviasi & 7,63 \\
Variansi & 58,31 \\
Rentang Skor & 35 \\
Nilai Terendah & 35 \\
Nilai Tertinggi & 70 \\
\hline
\end{tabular}


Jika skor hasil belajar matematika siswa kelas XAP SMK sebelum diterapkan metode PQ4R setting kooperatif dikelompokkan dalam lima kategori menurut Nurkancana (1986), maka diperoleh tabel distribusi frekuensi dan presentase hasil belajar seperti ditunjukkan pada tabel berikut ini:

Tabel 8. Distribusi Frekuensi hasil belajar matematika siswa (Pre-test) sebelum diajar dengan metode PQ4R setting kooperatif.

\begin{tabular}{cccc}
\hline Statistik & Kategori & Frekuensi & Persentase (\%) \\
\hline $0-54$ & Sangat rendah & 18 & 56 \\
$55-64$ & Rendah & 11 & 34 \\
$65-79$ & Sedang & 3 & 10 \\
$80-89$ & Tinggi & 0 & 0 \\
$90-100$ & Sangat tinggi & 0 & 0 \\
\hline Jumlah & & 32 & 100 \\
\hline
\end{tabular}

d. Hasil belajar matematika siswa setelah diajar dengan menggunakan metode PQ4R setting kooperatif (Posttest)

Hasil analisis statistik deskriptif berkaitan dengan skor variabel hasil belajar matematika siswa setelah diajar dengan menggunakan metode PQ4R setting kooperatif disajikan dalam tabel 9 berikut dan selengkapnya dapat dilihat pada lampiran

Tabel 9. Statistik Deskriptif hasil belajar matematika siswa (Post-test) setelah diajar dengan metode PQ4R setting kooperatif

\begin{tabular}{cc}
\hline Statistik & Nilai Statistik \\
\hline Ukuran sampel & 32 \\
Rata-rata & 81,38 \\
Nilai Tengah & 83,50 \\
Standar Deviasi & 6,86 \\
Variansi & 47.02 \\
Rentang Skor & 29 \\
Nilai Terendah & 65 \\
Nilai Tertinggi & 94 \\
\hline
\end{tabular}

Jika skor hasil belajar matematika siswa kelas XAP SMK setelah diterapkan metode PQ4R setting kooperatif dikelompokkan dalam lima kategori menurut Nurkancana (1986), maka diperoleh tabel distribusi frekuaensi dan presentase hasil belajar seperti ditunjukkan pada tabel berikut ini: 
Tabel 10. Distribusi Frekuensi Hasil belajar matematika siswa (Post-test) setelah diajar dengan metode PQ4R setting kooperatif

\begin{tabular}{cccc}
\hline Statistik & Kategori & Frekuensi & Persentase (\%) \\
\hline $0-54$ & Sangat rendah & 0 & 0 \\
$55-64$ & Rendah & 0 & 0 \\
$65-79$ & Sedang & 12 & 38 \\
$80-89$ & Tinggi & 18 & 56 \\
$90-100$ & Sangat tinggi & 2 & 6 \\
\hline Jumlah & & 32 & 100 \\
\hline
\end{tabular}

Dari skor rata-rata tersebut dapat disimpulkan bahwa prestasi belajar siswa kelas XAP SMK yang diajar dengan pembelajaran kooperatif metode tutor sebaya dan metode PQ4R setting kooperatif tergolong dalam kategori "tinggi".

e. N-Gain nilai Siswa yang diajar dengan menggunakan pembelajaran kooperatif metode tutor sebaya dan metode PQ4R setting kooperatif

Hasil analisis data nilai pretest dan posttest Siswa yang diajar dengan menggunakan pembelajaran kooperatif metode tutor sebaya dan metode PQ4R setting kooperatif disajikan dalam tabel berikut.

Tabel 11. Frekuensi N-Gain Hasil Belajar Siswa

\begin{tabular}{ccc}
\hline Klasifikasi & $\begin{array}{c}\text { Frekuensi N-Gain Hasil Belajar Siswa yang diajar dengan metode } \\
\text { Tutor Sebaya }\end{array}$ & $\begin{array}{c}\text { PQ4R } \\
\end{array}$ \\
\hline Rendah & 2 & 1 \\
Sedang & 23 & 26 \\
Tinggi & 7 & 5 \\
Rata-rata nilai N-Gain & 0.6 & 0.6 \\
Jumlah Siswa & 32 & 32 \\
\hline
\end{tabular}

Hasil Analisis Inferensial. Sebelum melakukan pengujian hipotesis, terlebih dahulu dilakukan uji normalitas dan uji homogenitas, karena hal ini merupakan syarat untuk melakukan pengujian hipotesis.

\section{Uji Normalitas}

Hasil analisis yang diperoleh sesuai dengan lampiran pada table Test of Normality menjelaskan hasil uji apakah data dapat dikatakan berdistribusi normal atau tidak. Keputusan yang diambil dari output SPSS 20,0 for windows yaitu nilai signifikan dari table Test of normality di kolom kolmogorov-smirnov dan Shapiro-wilk dengan pedoman pengambilan keputusan adalah:

a. Nilai probabilitas $<0,05$, distribusi adalah tidak normal (tidak simetris)

b. Nilai probabilitas $\leq 0,05$ distribusi normal (simetris) 
Berdasarkan hasil test of normality, menggunakan Shapiro-wilk, dari table tersebut terlihat bahwa nilai probabilitas untuk eksperimen I adalah 0,433 (lebih dari 0,05) dan nilai probabilitas untuk eksperimen II adalah 0,104 (lebih dari 0,05). Maka dapat disimpulan bahwa data pada eksperimen I berdistribusi normal (simetris) dan data pada eksperimen II juga berdistribusi normal

\section{Uji Homogenitas}

a. Jika taraf signifikasi $>0,05(\mathrm{p}>0,05)$ maka $\mathrm{H}_{0}$ diterima. Artinya, data berasal dari populasi yang homogen.

b. Jika taraf signifikasi $<0,05(\mathrm{p}<0,05)$ maka $\mathrm{H}_{0}$ ditolak. Artinya, data tidak berasal dari populasi yang homogen.

Berdasarkan hasil analisis pada data table "Test of Homogeinitas of Varience" terlihat dibaris Based on Mean, terlihat bahwa nilai signifikan yakni 0,141 yang lebih besar 0,05 . Juga jika dasar pengukuran adalah nilai $-p$ untuk median, terlihat bahwa nilai-p (based on median) adalah 0,124 yang lebih besar dari 0,05 maka kesimpulan diterima $\mathrm{H}_{0}$, sehingga dapat disimpulkan bahwa data berasal dari populasi yang mempunyai variansi yang sama.

\section{Pengujian Hipotesis}

Analisis inferensial statistika uji- $t$ diperoleh bahwa nilai $t$ hitung hasil belajar dengan Paired Sample Test adalah 0,430 dengan nilai $\mathrm{p}=0,670$. Karena yang diteliti adalah perbandingan hasil belajar maka uji pihak kanan dengan taraf signifikan $\alpha=0,05 \%$ atau $5 \%$. Oleh karena itu nilai $p$ $<0,05(0,670>0,005)$ maka $\mathrm{H}_{0}$ diterima sehingga dapat disimpulkan bahwa hasil rata-rata eksperimen I dan eksperimen II hasil belajar matematika siswa dengan pembelajaran kooperatif metode tutor sebaya sama dengan metode SQ4R setting kooperatif.

\section{Pembahasan}

Berdasarkan hasil analisis deskriptif nilai pretest hasil belajar matematika siswa kelas XAP1 diperoleh rata-rata sebesar 53,53 dengan standar deviasi 10,12 dan varians 102,45, sedangkan siswa kelas XAP2 diperoleh rata-rata 52,59 dengan standar deviasi 7,63 dan varians 58,31. Hasil analisis infirensial diperoleh nilai signifikansi normalitas sebesar 0,894 kelas XAP1 dan 0,943 kelas XAP2 yang menunjukkan bahwa data kedua kelompok kelas berdistribusi normal. Nilai signifikansi homogenitas based on mean sebesar 0.209 , serta based on median sebesar 0,220 yang menunjukkan bahwa data berasal dari kelompok yang homogen. Hal ini menunjukkan bahwa sampel berada pada kondisi awal yang sama, sehingga Sehingga untuk menentukan sampel dapat dilakukan dengan tehnik cluster random sampling. Sampel pada penelitian ini adalah kelas XAP1 sebagai kelas pembelajaran kooperatif Metode Tutor Sebaya dan kelas XAP2 sebagai kelas Metode SQ4R setting kooperatif.

Setelah dilakukan perlakuan diperoleh hasil analisis deskriptif nilai posttest hasil belajar matematika siswa kelompok eksperimen I adalah yang diajar melalui pembelajaran kooperatif metode tutor sebaya dikategorikan tinggi, hal ini ditunjukan dari perolehan nilai rata-rata posttest sebesar 82.22 atau tingkat dengan standar deviasi 7,29 dan varians 53,08. Nilai tinggi dan rendah yang dicapai oleh siswa adalah 98 dan 70. Sedangkan hasil belajar matematika yang diajar melalui metode SQ4R setting kooperatif dikategorikan tinggi, hal ini ditunjukan dari perolehan nilai rata- 
rata posttest sebesar 81,38 atau tingkat dengan standar deviasi 6,86 dan varians 47,02. Nilai tinggi dan rendah yang dicapai oleh siswa adalah 94 dan 65. Nilai rata-rata N-Gain kedua kelompok eksperimen adalah 0,6 yang menunjukkan bahwa keduanya memiliki besra pengaruh yang sama dalam pembelajaran matematika.

Hasil analisis inferensial diperoleh nilai signifikansi normalitas kelas eksperimen I sebesar 0,433 dan 0,104 untuk kelas eksperimen II, yang menunjukkan bahwa nilai signifikans $>0,05$ sehingga dapat disimpulkan bahwa kedua data berdistribusi normal. Nilai signifikansi homogenitas based on mean sebesar 0,141 , based on median sebesar 0,124 , yang $>0,05$, sehingga dapat disimpulkan bahwa data berasal populasi yang mempunyai variansi yang sama (homogen). Melalui hasil perhitungan analisis hipotesis dengan uji-t, diperoleh nilai $t=0,430$ dengan nilai $\mathrm{p}=0,670$. Hal ini menunjukkan bahwa nilai $\mathrm{p}>0,05$, maka $\mathrm{H}_{0}$ diterima sehingga dapat disimpulkan bahwa hasil rata-rata eksperimen I dan eksperimen II hasil belajar matematika siswa dengan pembelajaran kooperatif metode tutor sebaya sama dengan metode SQ4R setting kooperatif.

\section{Kesimpulan}

Berdasarkan hasil analisis data dan pembahasan hasil penelitian, maka disimpulkan bahwa terdapat pengaruh pembelajaran kooperatif metode tutor sebaya terhadap hasil belajar matamatika siswa kelas $\mathrm{X}_{\mathrm{AP}} \mathrm{SMK}$, terdapat pengaruh metode SQ4R setting kooperatif terhadap peningkatan hasil belajar matematika siswa $\mathrm{X}_{\mathrm{AP}} \mathrm{SMK}$, serta tidak terdapat perbedaan yang signifikan antara hasil belajar matamatika siswa kelas $\mathrm{X}_{\mathrm{AP}} \mathrm{SMK}$ yang diajar dengan pembelajaran kooperatif metode tutor sebaya memiliki pengaruh dan metode SQ4R setting kooperatif.

\section{Referensi}

\section{Jurnal}

Azlinah, N., Masriyah, (2014). Penerapan Metode Survey, Question, Read, Recite, Record, and Review (SQ4R) Pada Materi Aritmetika Sosial Di Kelas VII SMPN 1 Driyorejo Gresik. MATHEdunesa (Jurnal Ilmiah Pendidikan Matematika) 3(3): 175-181

Fitari, D.A., dkk. (2015). Penerapan Pembelajaran Kooperatif dengan Metode Problem Solving Meningkatkan Hasil Belajar Ipa SMP. Jurnal Pendidikan Biologi Indonesia 1(1): 99-108

Indriani, A.M.F., Mutmainnah, S. (2016). Metode Pembelajaran Tutor Sebaya Sebagai Upaya Meningkatkan Hasil Belajar Siswa. Journal of Accounting and Business Education. 2(2):

Siagian, R.E.F. (2015). Pengaruh Minat dan Kebiasaan Belajar Siswa Terhadap Prestasi Belajar Matematika. Jurnal Formatif 2(2): 122-131

\section{Buku}

Abdurrahman, Mulyono. (2009). Pendidikan Bagi Anak Berkesulitan Belajar. Jakarta: PT Rineka Cipta. 
Hamalik, O. (2009). Proses Belajar Mengajar. Bandung: Bumi Aksara.

Mudlofir, A. (2013). Pendidik Profesional. Jakarta: Rajawali persada.

Rusman. (2013). Model-Model Pembelajaran. Jakarta: Raja Grafindo Persada.

Sugiyono. (2014). Metode Penelitian Kuantitatif Kualitatif dan R\&D. Bandung: Alfabeta.

Trianto. (2009). Mendesain Model Pembelajaran Inovatif Progresif. Surabaya:Kencana.

Undang-Undang Republik Indonesia No. 20 Tahun 2003 Tentang Sistem Pendidikan Nasional. Jakarta: Depdiknas. 